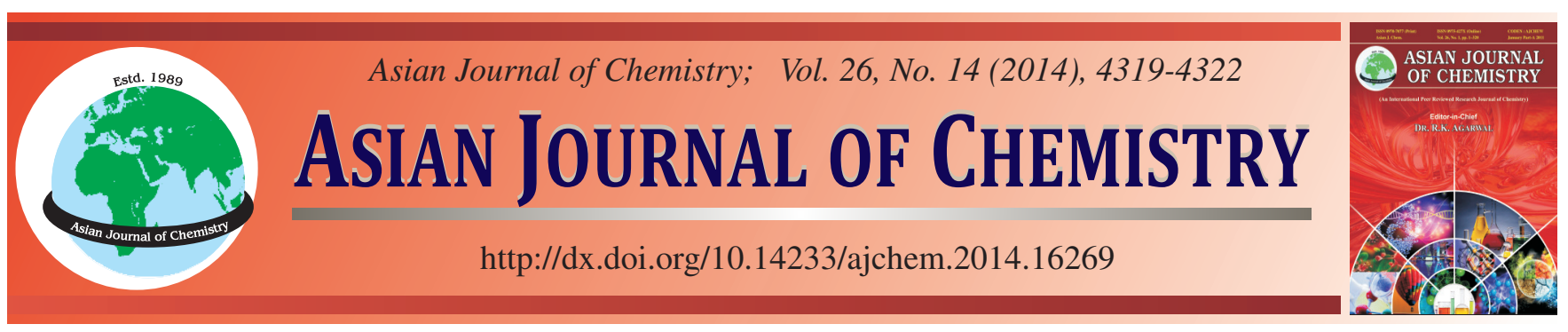

\title{
Variation of Physico-Chemical Attributes of Seed Oil Between Two Developing Cultivars of Sesame Grown Under Similar Agroclimatic Conditions in Pakistan
}

Naveed Ahmad ${ }^{1,2, *}$, Farooq Anwar ${ }^{2}$, Zahed Mahmood $^{1}$, Shaukat Ali Shahid ${ }^{3}$, Imran ShakiR ${ }^{4}$ and Shabnem Latif ${ }^{5}$

${ }^{1}$ Department of Chemistry \& Biochemistry, University of Agriculture, Faisalabad-38040, Pakistan

${ }^{2}$ Department of Chemistry, University of Sargodha, Sargodha-40100, Pakistan

${ }^{3}$ Department of Physics, University of Agriculture, Faisalabad-38040, Pakistan

${ }^{4}$ Deanship of Scientific Research College of Engineering, Post Office Box 800, King Saud University, Riyadh, Saudia Arabia

${ }^{5}$ Department of Pharmacy, Euro Campus, Hajvery University, Lahore-54000, Pakistan

*Corresponding author: E-mail: mnavedahmad@yahoo.com

Received: 2 September 2013;

Accepted: 22 November 2013;

Published online: 5 July 2014;

AJC-15466

The present work appraises variation of physico-chemical attributes of seed oils between two cultivars (V-96006 \& V-90005) of sesame (Sesamum indicum L.) grown under similar agroclimatic conditions. Sesame seeds of cultivar V-96006 \& V-90005 had oil, 41.20 and $46.95 \%$; moisture, 8.09 and $9.54 \%$; protein, 32.05 and $30.19 \%$; fiber, 2.41 and $2.10 \%$ while ash 4.39 and $4.78 \%$, respectively. The extracted sesame seed oils had iodine value between 107 and 110 ( $\mathrm{g}$ of I/100 g of oil), refractive index $\left(40{ }^{\circ} \mathrm{C}\right) 1.4624$ and 1.4638 , density $\left(24{ }^{\circ} \mathrm{C}\right) 0.87$ and $0.88 \mathrm{mg} / \mathrm{mL}$, free fatty acids 0.49 and $0.54 \%$, saponification value 190.24 and $190.95 \mathrm{mg}$ of $\mathrm{KOH} / \mathrm{g}$ of oil and unsaponifiable matter 2 and $2.60 \%$, respectively. The tested oils, in terms of measurements of peroxide value $(1.96-2.20 \mathrm{meq} / \mathrm{kg})$, conjugated dienes (2.01-2.38) and conjugated trienes (0.64-0.66) exhibited good oxidative state. The amounts of total tocopherols $(\alpha, \gamma$ and $\delta$ ) in the tested sesame oils of V-96006 \& V-90005 cultivars were found to be 619.5 and $644.6 \mathrm{mg} / \mathrm{kg}$, respectively with $\gamma$-tocopherol as the principal compound. GLC analysis of the oils revealed the occurrence of mainly linoleic acid $\left(\mathrm{C}_{18: 2}\right) 44.52$, $44.27 \%$; oleic acid $\left(C_{18: 1}\right)$ 39.34, $40.07 \%$; palmitic acid $\left(C_{16: 0}\right)$ 9.82, $9.23 \%$ and stearic acid $\left(C_{18: 0}\right)$ 5.21, $4.98 \%$, respectively. Small amount of linolenic acid $\left(\mathrm{C}_{18: 3}\right)<1.0 \%$ was also detected. The results of the present study showed that both of these sesame cultivars, except tocopherols, have comparable physico-chemical attributes and thus advocate selection of this potential oil seed crop for cultivation under the local agroclimatic conditions to produce good quality high-linoleic oil.

Keywords: Sesame, Oil extraction, Fatty acids, Tocopherols, HPLC, GLC, Oxidative stability.

\section{INTRODUCTION}

Sesame (Sesamum indicum L.) is one of the most ancient oilseed crops well known for its food, feed and health benefits due to high amount of antioxidant compounds ${ }^{1-3}$. Extensive cultivation of sesame in Asia and Africa has been reported for centuries due to its high content of good quality oil ${ }^{4}$. Its seed oil is valued commercially because of its high stability, nutritional value and therapeutic potential, while its meal, left after oil extraction, can be used as animal feed ${ }^{5}$. Besides their importance as a good source of edible oil, sesame seeds are reported to be used in baked and confectionery products ${ }^{6,7}$. The presence of neutraceutical compounds such as antioxidant phenolics and tocopherols in sesame seeds can be linked to the physiological functions such as anti-inflammatory activity and decreased incidence of blood pressure, aging and cardiovascular diseases, of this potential oil seed crop $^{8-11}$. Sesame lignin compounds have potential to exhibit antioxidant activity $^{12-14}$ and anti-carcinogenic effects ${ }^{15}$, as well as lowering of blood pressure ${ }^{16,17}$ and serum lipids ${ }^{18,19}$.

The oil yield and the physico-chemical properties of the oils produced not only vary among crop cultivars nevertheless these depend upon the agroclimatic conditions employed for their harvesting. The present comprehensive research work was aimed to investigate and compare the physico-chemical characteristics as well as the oxidative state, fatty acids and tocopherols profile of sesame oils between two cultivars of this potential oilseed crop grown under identical agroclimatic conditions.

\section{EXPERIMENTAL}

The seeds of two newly developed cultivars (V-96006 and V-90005) of sesame were harvested from different locations of the experimental fields of Ayub Agriculture Research Institute (AARI), Faisalabad, Pakistan. Three different seed samples for each of the cultivar/line were harvested. 
All the chemicals/reagents both analytical grade and HPLC grade used in the present work, were got from Merck (Darmstadt, Germany) or Sigma Aldrich (Buchs, Switzerland). The standards including that of tocopherols [DL- $\alpha$-tocopherol, (+) $\delta$-tocopherol, (+) $\gamma$-tocopherol] and the fatty acids methyl esters (FAMEs) were obtained from Sigma Chemical Co.

Oil extraction: The clean seeds were conditioned at $65^{\circ} \mathrm{C}$ for $0.5 \mathrm{~h}$ by placing in a hot air oven. The conditioned seed material, after grinding, was placed in a paper thimble and fed into a Soxhlet apparatus. The oil extraction was carried out for $6 \mathrm{~h}$ with $n$-hexane (b.p $65-68^{\circ} \mathrm{C}$ ). After oil recovery, the excess of the solvent was removed under vacuum using a rotary evaporator (EYELA, N.N. Series, Rikakikai Co. Ltd., Tokyo, Japan).

Analysis of oilseed residues: After the removal/recovery of oil, sesame oilseed residue (meal), was analyzed for protein, fiber and ash contents following AOAC method ${ }^{20}$, ISO method ${ }^{21}$ and ISO method ${ }^{22}$, respectively.

Analysis of extracted oils: Density, iodine value, peroxide value, refractive index, acidity, saponification value and unsaponifiable matter of the recovered sesame seed oils were determined according to AOCS standard method ${ }^{23}$. Color intensity was measured using a Lovibond Tintometer (Tintometer Ltd., Salisbury, Wiltshire, United Kingdom). The tested seed oils were analyzed by a spectrophotometer (U-2001, Hitachi Instrument Inc. Tokyo, Japan) for the estimation of specific extinctions (conjugated dienes and conjugated trienes) after taking the absorbance at $232 \mathrm{~nm}$ and $270 \mathrm{~nm}$, respectively. The samples of oils were diluted with iso-octane to bring the absorbance of the sample solution within the appropriate range and $\left(\varepsilon_{1}{ }^{1 \%} \mathrm{~cm}(\lambda)\right)$ was determined according to IUPAC method after taking the absorbance ${ }^{24}$. The extracted oils were also analyzed for $p$-anisidine value using IUPAC protocol ${ }^{24}$. For this measurement, the oils were diluted in iso-octane and reacted with $p$-anisidine reagent to produce colored complex, the intensity of which was measured at $350 \mathrm{~nm}$ using the specified spectrophotometer.

Tocopherol content: The qualitative and quantitative measurement of the oil tocopherols ( $\alpha, \gamma$ and $\delta$ ) was made using high performance liquid chromatography (HPLC) following the CPFA (Current Protocols in Food Analytical Chemistry) method $^{25}$. Accurately weighed amount $(0.1 \mathrm{~g})$ of the oil was mixed with $0.05 \mathrm{~g}$ ascorbic acid (AA) to protect from oxidation during sample preparation using protocol as described in one of our recent article ${ }^{26}$ and afterward analyzing it by normal phase HPLC. A $20-\mu \mathrm{L}$ of the prepared sample was injected into a Supelcosil LC-Si column $(250 \times 4.6 \mathrm{~mm}$, Supelco Inc., Supelco Park, Bellefonte, USA) and eluted with a mobile phase mixture (ethyl acetate/acetic acid/hexane; 1:1:98 v/v/v) at a flow rate of $1.5 \mathrm{~mL} / \mathrm{min}$. Identification of tocopherols $(\alpha, \gamma$ and $\delta$ ) was done at wavelength of $295 \mathrm{~nm}$. The peaks of unknown tocopherols were identified by comparing their retention times with those of pure standards while the quantification of these was made based upon comparison of peak areas with those of pure (authentic) standards.

Gas chromatographic fatty acid analysis: The seed oils under testing were converted into the respective fatty acid methyl esters (FAMEs) following the standard IUPAC method ${ }^{24}$ and then analyzed on a SHIMADZU gas chromatograph model
17-A, fitted with a SP-2330 (SUPLECO, Inc., Bellefonte, PA) methyl lignoserate coated polar capillary column $(30 \mathrm{~m} \times 0.25$ $\mathrm{mm})$ and a flame ionization detector. Pure nitrogen gas $(99.999 \%$ ) was used as a mobile phase at $5 \mathrm{~mL} / \mathrm{min}$ flow rate. The other analysis parameters were: split injector temperature $230{ }^{\circ} \mathrm{C}$; initial column oven temperature $180^{\circ} \mathrm{C}$ was increased with ramp rate $5^{\circ} \mathrm{C} / \mathrm{min}$ to final temperature $220^{\circ} \mathrm{C}$; detector temperature $240{ }^{\circ} \mathrm{C}$. FAMEs were identified based upon comparison of their retention times with those of authentic standards and were quantified by a data handling software (CSW) giving the composition as relative percentage of the total peak areas.

Statistical analysis: Three replicates were performed for each analysis and the data thus generated was statistical analyzed by STATISTICA 5.5 (Stat Soft Inc., Tulsa, Oklahoma, USA) software. Statistically significant differences of means between the lines were considered at $p<0.05$

\section{RESULTS AND DISCUSSION}

The oil content yielded (recovered) from the seeds of two sesame cultivars was found to be as high as $46.95 \%$ (Table- 1 ). The oil yield (46.95\%) of V-90005 was found to be significantly higher $(p<0.05)$ than that of V-96006 (41.20\%). Sesame seed oil content (41.20-46.95\%) obtained in the present research work was noted to be higher than the findings of Gul et $a l .{ }^{27}$ while it was lower than the value investigated by ElKheir et al. ${ }^{28}$, Mohammed and Hamza ${ }^{29}$, Unal and Yalcin ${ }^{30}$ and Nzikou et al. ${ }^{31}$. This difference in the oil yield across the regions might be attributed to varied genetic make up of the varieties as well differing agroclimatic conditions of the harvesting ${ }^{32}$.

\begin{tabular}{|c|c|c|}
\hline \multicolumn{3}{|c|}{$\begin{array}{l}\text { TABLE-1 } \\
\text { PROXIMATE ANALYSIS OF SESAME } \\
\text { SEED OF TWO CULTIVARS }\end{array}$} \\
\hline & V-96006 & V-90005 \\
\hline Oil Content (\%) & $41.20 \pm 0.91^{b}$ & $46.95 \pm 1.50^{\mathrm{a}}$ \\
\hline Moisture (\%) & $8.09 \pm 0.29^{b}$ & $9.54 \pm 0.31^{\mathrm{a}}$ \\
\hline Protein content $(\%)$ & $32.05 \pm 1.23^{\mathrm{a}}$ & $30.19 \pm 1.10^{\mathrm{a}}$ \\
\hline Fiber Content $(\%)$ & $2.41 \pm 0.24^{\mathrm{a}}$ & $2.10 \pm 0.16^{\mathrm{a}}$ \\
\hline Ash Content (\%) & $4.39 \pm 0.25^{\mathrm{a}}$ & $4.78 \pm 0.21^{\mathrm{a}}$ \\
\hline \multicolumn{3}{|c|}{$\begin{array}{l}\text { Values are mean } \pm \text { SD for three different samples of each cultivar } \\
\text { analyzed individually in triplicate. Different superscript letters within } \\
\text { the same row indicate significant }(p<0.05) \text { differences of means } \\
\text { between the investigated cultivars }\end{array}$} \\
\hline
\end{tabular}

Analysis of the meal (oilseed residue left after oil removal) revealed that seed of V-96006 contained slightly higher protein $(32.05 \%)$ than that of $\mathrm{V}-90005(30.19 \%)$. This protein content (30.19-32.05\%) of sesame seed is comparable with the findings of El-Kheir et al. ${ }^{28}$ but higher than that investigated by Unal and Yalcin ${ }^{30}$ and Nzikou et al. ${ }^{31}$. The present study revealed that sesame seed meal could be a good source of vegetable protein for uses as animal or poultry feed. Fiber content $(2.10-2.41 \%)$ in the sesame seed was found to be lower than the values reported by Gul et al. ${ }^{27}$, El-Kheir et al. ${ }^{28}$ and Nzikou et $a l .^{31}$. The fiber content indicates the indigestibility of food stuff. There was no significant difference $(p>0.05)$ for protein, ash and crude fiber contents between the two sesame seed cultivars/lines (V-96006 and V-90005) used. 
The seed oils obtained were evaluated for quality-related and routine physico-chemical parameters (Table-2). The oil from both the cultivars (V-96006 \& V-90005) was found to have color index of $4 \mathrm{R}+40 \mathrm{Y}, 3.6 \mathrm{R}+36 \mathrm{Y}$ and density 0.88 , $0.87 \mathrm{mg} / \mathrm{mL}$, respectively. The color index of oil is linked with the presence of different coloring pigments. Lower color index of oil makes it appropriate for edible and domestic applications while high color intensity may adversely affect commercial value of oil. The present saponification value (190.24-190.59 $\mathrm{mg}$ of $\mathrm{KOH} / \mathrm{g}$ of oil) was slightly higher than the findings of Gul et al. ${ }^{27}$, El-Kheir et al..$^{28}$, Latif and Anwar ${ }^{33}$ and comparable with the data of Mohammed and Hamza ${ }^{29}$. A higher saponification value of the oil supports their uses for production of liquid soap, shampoos and shaving creams. The unsaponifiable matter (2.0-2.60\%) of sesame seed oils was higher than that findings of Gul et al. ${ }^{27}$, Nzikou et al. ${ }^{31}$, Latif and Anwar ${ }^{32}$. The refractive index (1.4624-1.4638) of tested oils was comparable to the values reported by Gul et al. ${ }^{27}$, El-Kheir et al. ${ }^{28}$, Latif and Anwar ${ }^{33}$.

\begin{tabular}{|c|c|c|}
\hline \multicolumn{3}{|c|}{$\begin{array}{c}\text { TABLE-2 } \\
\text { PHYSICOCHEMICAL CHARACTERISTICS OF } \\
\text { SESAME SEED OIL OF TWO CULTIVARS }\end{array}$} \\
\hline & V-96006 & V-90005 \\
\hline Refractive Index $\left(40^{\circ} \mathrm{C}\right)$ & $1.4638 \pm 0.003^{\mathrm{a}}$ & $1.4624 \pm 0.004^{\mathrm{a}}$ \\
\hline Color Unit (Red Unit) & $4.00 \pm 0.12^{\mathrm{a}}$ & $3.60 \pm 0.09^{b}$ \\
\hline Color Unit (Yellow Unit) & $40.00 \pm 1.80^{\mathrm{a}}$ & $36.00 \pm 1.48^{\mathrm{a}}$ \\
\hline Density $(\mathrm{mg} / \mathrm{mL})\left(24^{0} \mathrm{C}\right)$ & $0.88 \pm 0.01^{\mathrm{a}}$ & $0.87 \pm 0.02^{\mathrm{a}}$ \\
\hline $\begin{array}{l}\text { Saponification Value (mg of } \\
\mathrm{KOH} / \mathrm{g} \text { of oil) }\end{array}$ & $190.95 \pm 2.50^{\mathrm{a}}$ & $190.24 \pm 3.46^{\mathrm{a}}$ \\
\hline Unsaponifiable matter $(\%)$ & $2.00 \pm 0.06^{\mathrm{b}}$ & $2.60 \pm 0.09^{\mathrm{a}}$ \\
\hline $\begin{array}{l}\text { Iodine value ( } \mathrm{g} \text { of } \mathrm{I}_{2} / 100 \mathrm{~g} \\
\text { of oil) }\end{array}$ & $110.00 \pm 2.16^{\mathrm{a}}$ & $107.00 \pm 2.91^{a}$ \\
\hline Free Fatty Acid ( $\%$ as oleic acid) & $0.54 \pm 0.04^{\mathrm{a}}$ & $0.49 \pm 0.05^{\mathrm{a}}$ \\
\hline \multicolumn{3}{|c|}{$\begin{array}{l}\text { Values are mean } \pm \text { SD for three different samples of each cultivar analyzed } \\
\text { individually in triplicate. Different superscript letters within the same row } \\
\text { indicate significant }(p<0.05) \text { differences of means between the } \\
\text { investigated cultivars }\end{array}$} \\
\hline
\end{tabular}

The free fatty acid (FFA) value (0.49-0.52\% as oleic acid) of extracted seed oils was comparable to the findings of Gul et al. ${ }^{27}$, Mohammed and Hamza ${ }^{29}$, Latif and Anwar ${ }^{33}$ but lower than the values reported by El-Kheir et al. ${ }^{28}$ and Nzikou et al. ${ }^{31}$. Free fatty acid index is directly correlated with the deterioration of the oils and provides favorable conditions for the development of objectionable flavor and odor. A low free fatty acid value for sesame oil in the present study showed good resistance to hydrolysis. Iodine value is used to measure the degree of unsaturation of the oils ${ }^{34}$. The iodine value (107-110 $\mathrm{g}$ of $\mathrm{I} / 100 \mathrm{~g}$ of oil) of the tested oils was found to be in line with the values investigated by Gul et al. ${ }^{27}$, El-Kheir et al. $^{28}$, Mohammed and $\mathrm{Hamza}^{29}$, Latif and Anwar ${ }^{32}$. No significant $(p>0.05)$ difference was observed for routine physico-chemical parameters between the oils extracted from both the tested sesame cultivars except unsaponifiable matter.

Sesame seed oils exhibited good oxidation stability as evident by the data presented in Table-3. Somali et al. ${ }^{35}$ reported that the oxidative deterioration and purity of the oil can be appraised by measuring the specific extinctions (conjugated dienes and conjugated trienes) at $232 \mathrm{~nm}$ and $270 \mathrm{~nm}$, respectively. The tested oils (V-96006 \& V-90005) showed specific extinctions as high as $2.38,2.01$ at $232 \mathrm{~nm}$ while $0.64,0.66$ at
$270 \mathrm{~nm}$, respectively, revealing non significant $(p>0.05)$ variation between the two cultivars tested. Peroxide value of sesame seed oil (V-96006 and V-90005) was found to be 1.96 and 2.2 $\mathrm{meq} / \mathrm{kg}$, respectively, showing significant $(p<0.05)$ difference between the two tested sesame oils. The peroxide value of the analyzed oil (1.96-2.2 meq/kg of oil) was higher than the findings of Nzikou et al. ${ }^{31}$ and Latif and Anwar ${ }^{33}$. $p$-Anisidine value measures hydro-peroxides and aldehydic secondary oxidation products of the oils $\mathrm{s}^{35}$. Sesame seed oil exhibited $p$-anisidine value $(0.28-0.57)$ showing its good resistance to oxidation. It was found that V-90005 have significantly $(p<0.05)$ higher $p$-anisidine value (0.28) than that of V-96006 (0.57).

\begin{tabular}{|c|c|c|}
\hline \multicolumn{3}{|c|}{$\begin{array}{c}\text { TABLE-3 } \\
\text { OXIDATIVE STATE OF SESAME SEED } \\
\text { OIL OF TWO CULTIVARS }\end{array}$} \\
\hline & V-96006 & V-90005 \\
\hline Conjugateddienes $\varepsilon_{1}{ }^{1 \%}{ }_{\mathrm{cm}}(\lambda)(\lambda=232)$ & $2.38 \pm 0.04^{\mathrm{a}}$ & $2.01 \pm 0.05^{b}$ \\
\hline Conjugated trienes $\varepsilon_{1}{ }^{1 \%}{ }_{\mathrm{cm}} \lambda,(\lambda=68)$ & $0.64 \pm 0.04^{\mathrm{a}}$ & $0.66 \pm 0.05^{\mathrm{a}}$ \\
\hline P-Anisidine value & $0.57 \pm 0.01^{\mathrm{a}}$ & $0.28 \pm 0.01^{\mathrm{b}}$ \\
\hline Peroxide Value (meq/Kg ) & $2.2 \pm 0.05^{\mathrm{a}}$ & $1.96 \pm 0.06^{b}$ \\
\hline \multicolumn{3}{|c|}{$\begin{array}{l}\text { Values are mean } \pm \text { SD for three different samples of each cultivar } \\
\text { analyzed individually in triplicate. Different superscript letters within } \\
\text { the same row indicate significant }(p<0.05) \text { differences of means } \\
\text { between the investigated cultivars }\end{array}$} \\
\hline
\end{tabular}

The amounts of tocopherols ( $\alpha, \gamma$ and $\delta$ ) in the seeds oils recovered from two sesame cultivars (V-96006 \& V-90005) are given in Table- 4 . The tested oils had small amount of $\alpha$ tocopherol $(3.6 \mathrm{mg} / \mathrm{kg} \& 4.1 \mathrm{mg} / \mathrm{kg})$ and $\gamma$-tocopherol $(2.9$ $\mathrm{mg} / \mathrm{kg} \& 3.5 \mathrm{mg} / \mathrm{kg}$ ) while a very high amount of $\gamma$-tocopherol $(613 \mathrm{mg} / \mathrm{kg} \& 637 \mathrm{mg} / \mathrm{kg})$, respectively. Meanwhile, the concentration of $\gamma$-tocopherol was noted to be varied insignificantly $(p>0.05)$ between the varieties tested. $\gamma$-tocopherol $(3.6 \&$ $4.1 \mathrm{mg} / \mathrm{kg}$ ) in sesame seed oil, which has the greatest vitamin E potency $^{36}$, was lower than the findings of Gul et al. ${ }^{27}$ and higher than the values reported by Latif and Anwar ${ }^{33}$. The amount of $\delta$-tocopherol $(2.9 \& 3.5 \mathrm{mg} / \mathrm{kg})$ in extracted oils was comparable to the findings of Latif and Anwar ${ }^{33}$ but lower than the value published by Gul et al. ${ }^{27}$. The level of $\gamma$-tocopherol (613$637 \mathrm{mg} / \mathrm{kg}$ ) in tested oils was found to be higher than the values reported by Latif and Anwar ${ }^{33}$.

\begin{tabular}{|c|c|c|}
\hline \multicolumn{3}{|c|}{$\begin{array}{c}\text { TABLE-4 } \\
\text { TOCOPHEROL CONTENTS OF SESAME } \\
\text { SEED OIL OF TWO CULTIVARS }\end{array}$} \\
\hline & V-96006 & V-90005 \\
\hline$\alpha$-Tocopherol (mg/kg) & $3.60 \pm 0.08^{b}$ & $4.10 \pm 0.14^{\mathrm{a}}$ \\
\hline$\gamma$-Tocopherol (mg/kg) & $613 \pm 7^{\mathrm{a}}$ & $637 \pm 5^{\mathrm{a}}$ \\
\hline$\delta$-Tocopherol (mg/kg) & $2.90 \pm 0.09^{b}$ & $3.50 \pm 0.10^{\mathrm{a}}$ \\
\hline \multicolumn{3}{|c|}{$\begin{array}{l}\text { Values are mean } \pm \text { SD for three different samples of each cultivar } \\
\text { analyzed individually in triplicate. Different superscript letters within } \\
\text { the same row indicate significant }(p<0.05) \text { differences of means } \\
\text { between the investigated cultivars }\end{array}$} \\
\hline
\end{tabular}

The fatty acid composition of sesame seed oils analyzed is given in Table-5. The contents of total saturated fatty acids in the extracted oils from the tested cultivars namely V-96006 \& V-90005 were found to be $14.52-15.38 \%$ followed by mono unsaturated fatty acids $s^{39} .34-40.07 \%$ and poly unsaturated fatty acids $45.16-45.86 \%$. The amount of the total saturated fatty 


\begin{tabular}{|c|c|c|}
\hline \multicolumn{3}{|c|}{$\begin{array}{l}\text { TABLE-5 } \\
\text { FATTY ACID COMPOSITION OF SESAME } \\
\text { SEED OIL OF TWO CULTIVARS }\end{array}$} \\
\hline Fatty acids & V-96006 & V-90005 \\
\hline C16:0 & $9.82 \pm 0.29^{\mathrm{a}}$ & $9.23 \pm 0.18^{a}$ \\
\hline C18:0 & $5.21 \pm 0.10^{\mathrm{a}}$ & $4.98 \pm 0.15^{a}$ \\
\hline C18:1 & $39.34 \pm 0.71^{\mathrm{a}}$ & $40.07 \pm 0.79^{a}$ \\
\hline C18:2 & $44.52 \pm 1.21^{\mathrm{a}}$ & $44.27 \pm 0.95^{\mathrm{a}}$ \\
\hline C18:3 & $0.59 \pm 0.01^{\mathrm{a}}$ & $0.64 \pm 0.02^{\mathrm{a}}$ \\
\hline $\mathrm{C} 20: 0$ & $0.35 \pm 0.02^{\mathrm{a}}$ & $0.31 \pm 0.01^{\mathrm{a}}$ \\
\hline \multicolumn{3}{|c|}{$\begin{array}{l}\text { Values are mean } \pm \text { SD for three different samples of each cultivar } \\
\text { analyzed individually in triplicate. Different superscript letters within } \\
\text { the same row indicate significant }(p<0.05) \text { differences of means } \\
\text { between the investigated cultivars }\end{array}$} \\
\hline
\end{tabular}

acid (14.52-15.38 \%) in the presently examined seed oils was lower than the findings of Gul and $\mathrm{Zreen}^{27}$ and comparable to the values reported by El-Kheir et al. ${ }^{28}$, Unal and Yalcin ${ }^{30}$, Nzikou et al. ${ }^{31}$, Latif and Anwar ${ }^{32}$. Linoleic acid is one of the most important polyunsaturated fatty acids which provide protection against vascular heart diseases ${ }^{37}$.

The tested oils contained linoleic acid $\left(\mathrm{C}_{18: 2}, \mathrm{n}-6\right)$ as a dominant poly unsaturated fatty acid (44.27-44.52\%) followed by oleic acid $\left(\mathrm{C}_{18: 1} ; \mathrm{n}-9\right)$ as mono unsaturated fatty acid (39.34$40.07 \%)$ and palmitic $\left(\mathrm{C}_{16: 0}\right)$ as a dominant saturated fatty acid (9.23-9.82\%). A small amount (0.59-0.64\%) of linolenic acid $\left(\mathrm{C}_{18: 3}, \mathrm{n}-3\right)$ was also detected in the tested oils. The content of oleic acid $\left(\mathrm{C}_{18: 1}\right)(39.34-40.07 \%)$ in the present study was comparable to the findings of Gul et al. ${ }^{27}$, Nzikou et al. ${ }^{31}$, Latif and Anwar ${ }^{33}$ but lower than the values reported by El-Kheir et al. ${ }^{28}$, Unal and Yalcin ${ }^{30}$. The amount of linoleic acid $\left(\mathrm{C}_{18: 2}\right)$ (44.27-44.52\%) was comparable to the findings of Latif and Anwar ${ }^{33}$, while higher than the values reported by El-Kheir et $a^{28}$. Unal and Yalcin ${ }^{30}$ and lower than the value published by Nzikou et $a l .^{31}$.

\section{Conclusion}

It could be concluded from the results of this study that most of the physico-chemical characteristics of the oils produced under similar trial fields and conditions were varied insignificantly $(p>0.05)$ between the two tested sesame cultivars indicating that both of the cultivars have close resemblance for the genetic make up. Overall, the seed oils investigated contained predominant amount of linoleic acid and oleic acid, reasonable oxidative stability along with appreciable level of tocopherols. It would be valuable to cultivate these lines of sesame locally to produce oil with consistent quality. Production of oils from such non-conventional oilseed crops such in Pakistan can be helpful to bridge the gap between domestic demand (3.5 million tons) and local supply/production (around 1 million tons) of vegetable oils thus a step forward towards saving of huge amount of foreign exchange.

\section{ACKNOWLEDGEMENTS}

The authors extended their sincere appreciation to the Deanship of Scientific Research at King Saud University for funding of this research through the research Group Project No. RGP-VPP-312.

\section{REFERENCES}

1. D. Bedigian and J.R. Harlan, Econ. Bot., 40, 137 (1986).

2. H.A. Abou-Gharbia, F. Shahidi, A. Adel, Y. Shehata and M.M. Youssef, J. Am. Oil Chem. Soc., 74, 215 (1997).

3. I. Tomazic and Z. Korosec-Koruza, Genet. Resour. Crop Evol., 50, 779 (2003).

4. S.S. Desphande, U.S. Desphande, D.K. Salunkhe and Y.H. Hui, Sesame Oil, In: Bailey's Industrial Oil and Fat Products, Interscience Publishers: New York, edn 5, pp. 457-497 (1996).

5. M.V. Reshma, C. Balachandran, C. Arumughan, A. Sunderasan, D. Sukumaran, S. Thomas and S.S. Saritha, Food Chem., 120, 1041 (2010).

6. L. Ashakumary, I. Rouyer, Y. Takahashi, T. Ide, N. Fukuda, T. Aoyama, T. Hashimoto, M. Mizugaki and M. Sugano, Metabolism, 48, 1303 (1999).

7. A.A. Moazzami, Ph.D. Thesis, Sesame Seed Lignans: Diversity, Human Metabolism and Bioactivities, Swedish University of Agricultural Sciences, Uppsala, Sweden (2006); ISBN 91-576-7147-8.

8 B. Jannat, M. Oveisi, N. Sadeghi, M. Hajimahmoodi, M. Behzad, E. Choopankari and A.A. Behfar, Iran J. Environ. Health, 7, 97 (2010).

9. F. Hirata, K. Fujita, Y. Ishikura, K. Hosoda, T. Ishikawa and H. Nakamura, Atherosclerosis, 122, 135 (1996).

10. Y. Matsumura, S. Kita, Y. Tanida, Y. Taguchi, S. Morimoto, K. Akimoto and T. Tanaka, Biol. Pharm. Bull., 21, 469 (1998).

11. M. Hajimahmoodi, M.R. Oveisi, N. Sadeghi, B. Jannat, Z. Bahaeddin and S. Mansoori, Iran. J. Pharm. Res., 7, 135 (2008).

12. G.A. Crosby, Food Technol., 59, 32 (2005).

13. K. Yamashita, Y. Nohara, K. Katayama and M. Namiki, J. Nutr., 122, 2440 (1992).

14. K. Akimoto, Y. Kitagawa, T. Akamatsu, N. Hirose, M. Sugano, S. Shimizu and H. Yamada, Ann. Nutr. Metab., 37, 218 (1993).

15. N. Hirose, F. Doi, T. Ueki, K. Akazawa, K. Chijiiwa, M. Sugano, K. Akimoto, S. Shimizu and H. Yamada, Anticancer Res., 12, 1259 (1992).

16. Y. Matsumura, S. Kita, S. Morimoto, K. Akimoto, M. Furuya, N. Oka and T. Tanaka, Biol. Pharm. Bull., 18, 1016 (1995).

17. Y. Matsumura, S. Kita, Y. Tanida, Y. Taguchi, S. Morimoto, K. Akimoto and T. Tanaka, Biol. Pharm. Bull., 21, 469 (1998).

18. N. Hirose, T. Inoue, K. Nishihara, M. Sugano, K. Akimoto, S. Shimizu and H. Yamada, J. Lipid Res., 32, 629 (1991).

19. M. Namiki, Food Rev. Int., 11, 281 (1995).

20. Association of Official Analytical Chemists (AOAC), Official Methods of Analysis of the Association of Official Analytical Chemists, AOAC Inc., Virginia, Method 976.05, edn 15 (1990).

21. International Organization for Standardization (ISO), Animal Feeding Stuffs Determination of Nitrogen and Calculation of Crude Protein Contents, ISO, Geneva, Standard No. 5983 (1981).

22. International Organization for Standardization (ISO), Oilseeds Residues Determination of Total Ash, ISO, Geneva, Standard No.749 (1977).

23. American Oil Chemist's Society (AOCS), Official and Recommended Practices of the American Oil Chemists Society, AOCS Press, Champaign, edn 5 (1997).

24. C. Paquot and A. Hautfenne, International Union of Pure and Applied Chemistry (IUPAC), Standard methods for the analysis of oils, fats and derivatives, Blackwell Scientific, London, Revised and Enlarged edn. 7 (1987).

25. R.E. Wrolstad, Analysis of Tocopherols and Tocotrienols, In Current Protocols in Food Analytical Chemistry, John Wiley \& Sons, U.K. (2003).

26. S. Latif and F. Anwar, J. Am. Oil Chem. Soc., 86, 393 (2009).

27. T. Gul and Z. Zreen, Asian J. Chem., 23, 2064 (2011).

28. M.K.S. El Khier, K.E.A. Ishag and A.E.G.A. Yagoub, Res. J. Agric. Biol. Sci., 4, 761 (2008).

29. M.I. Mohammed and Z.U. Hamza, J. Appl. Sci. Environ. Manage., 12, 99 (2008).

30. M.K. Unal and H. Yalcin, Grasas Y. Aceites, 59, 23 (2008).

31. J.M. Nzikou, M. Mvoula-Tsieri, C.B. Ndangui, N.P.G. Pambou-Tobi, A. Kimbonguila, B. Loumouamou, T. Silou and S. Desobry, Res. J. Appl. Sci. Eng. Technol., 2, 227 (2010).

32. S. Latif and F. Anwar, Food Chem., 125, 679 (2011).

33. M.K. Egbekun and M.U. Ehieze, Plant Foods Hum. Nutr., 51, 35 (1997).

34. S.O. Ibiyemi, T.O. Adepoju, S.O. Okanlawon and V.O. Fadipe, Nig. J. Nutr. Sci., 13, 31 (1992).

35. M.A. Somali, M.A. Bajneid and S.S. Al-Fhaimani, J. Am. Oil Chem. Soc., 61, 85 (1984).

36. J.B. Rossell, in eds.: J.B. Rossell and J.L.R. Pritchard, Vegetable Oils and Fats, In Analysis of Oils, Fats and Fatty Foods, Elsevier Applied Sciences, New York, pp. 261-327 (1991).

37. C. Boelhouwer, J. Am. Oil Chem. Soc., 60, 457 (1983). 